\title{
The Missing Transmission Mechanism in the Monetary Explanation of the Great Depression
}

\author{
By Christina D. Romer and David H. Romer**
}

For many, Friedman and Schwartz's Monetary History of the United States (1963) is synonymous with the notion that monetary contraction and errors by the Federal Reserve caused the Great Depression. But this quick summary both sells the book short and oversells its findings about the 1930s.

It sells the book short because the contributions of the Monetary History extend far beyond the Depression. Friedman and Schwartz use an extensive reading of the historical record over nearly a century to identify times when the money supply moved for reasons unrelated to current or prospective macroeconomic conditions. That output moved in the same direction as money following these "crucial experiments" remains some of the strongest evidence we have that monetary shocks have real effects.

But saying the book proves that monetary shocks caused the Depression is a stretch. Of the monetary shocks Friedman and Schwartz identify, those early in the Depression are arguably the most tenuous. And crucially, the book provides scant discussion of how monetary shocks affect the economy. This weakness is most pressing in the analysis of the Depression. Because nominal interest rates fell precipitously early in the Depression and remained low throughout, it is hard to appeal to the standard transmission mechanism operating through the nominal cost of credit.

This paper seeks to fill in the missing transmission mechanism in Friedman and Schwartz's explanation of the Depression. In Section I, we describe previous work showing that falling

\footnotetext{
*C. Romer: University of California, Berkeley, CA 94720 (e-mail: cromer@econ.berkeley.edu); D. Romer: University of California, Berkeley, CA 94720 (e-mail: dromer@econ. berkeley.edu).

$\uparrow$ To view additional materials, and author disclosure statement(s), visit the article page at http://dx.doi.org/10.1257/aer.103.3.66.
}

nominal interest rates could be consistent with monetary contraction if there were expectations of deflation. But we argue that the monetary explanation requires not just that there were such expectations, but that they were the result of monetary contraction.

In Section II, we analyze one component of the business press in detail to see if there was a link between monetary shocks and expectations of deflation in the central years of the Depression. We find evidence that professional observers did indeed expect deflation in substantial part because of Federal Reserve behavior and monetary contraction. This suggests that monetary shocks in the Depression may have affected output and employment by raising real interest rates.

\section{Challenges to the Monetary Explanation}

The core of the Monetary History's treatment of the Depression (Chapter 7) is a careful historical analysis of the underlying reasons for the decline in the money stock in the early 1930s. This is where Friedman and Schwartz make their case that the monetary decline was relatively exogenous to the decline in output.

One monetary shock they identify in this period is the Federal Reserve Bank of New York's decision to raise the discount rate by 200 basis points in October 1931 following Britain's departure from the gold standard. The resulting fall in the money stock was clearly not an endogenous reaction to the fall in output, but the result of the decision to defend the gold standard.

Friedman and Schwartz suggest that there were other monetary shocks in 1929-1931. Their argument is that the Federal Reserve stood by as banking panics caused large declines in the money multiplier, and hence in the supply of money, and that under either the previous clearinghouse system or a better functioning central bank, such drops in the money supply would not have occurred. 
In Chapter 7, the role of the monetary contraction in causing the real decline is largely implicit. Only after Friedman and Schwartz bring in other episodes-1920, 1936-1937, and perhaps the panics under the National Banking System-do they have a clear case that exogenous monetary contractions cause output contraction. Armed with that relationship, one can then go back to the 1930s and say that since there were large exogenous monetary contractions in this period, they likely caused much of the real decline.

\section{A. The Anomalous Behavior of Nominal Interest Rates}

The Monetary History is almost entirely reduced form. It focuses on the evidence that output and prices fell after monetary shocks. It provides little discussion and virtually no evidence on the possible transmission mechanism of monetary shocks to the economy.

Most scholars have assumed that Friedman and Schwartz had in mind a conventional interest-rate channel. In the textbook IS-LM model, a reduction in the money supply shifts the LM curve back and raises nominal and real interest rates.

Figure 1 shows the monthly prime commercial paper rate for 1925 to 1933 . 1 There was a sharp rise in nominal interest rates after the October 1931 increase in the discount rate. Interest rates also rose noticeably beginning in early 1928 . As described by Friedman and Schwartz and Hamilton (1987), the Federal Reserve tightened policy moderately in this period to try to rein in stock market speculation. However, other than these two times, the course of nominal interest rates during the Depression was strongly downward.

\section{B. Challenges to Friedman and Schwartz's Emphasis on Monetary Shocks}

The literature has responded to this anomalous behavior of nominal rates in two ways. One is to suggest that Friedman and Schwartz are simply wrong about the role of monetary shocks, at least in some time periods.

\footnotetext{
${ }^{1}$ The data are from Board of Governors of the Federal Reserve System (1943, Table 120, pp. 450-451).
}

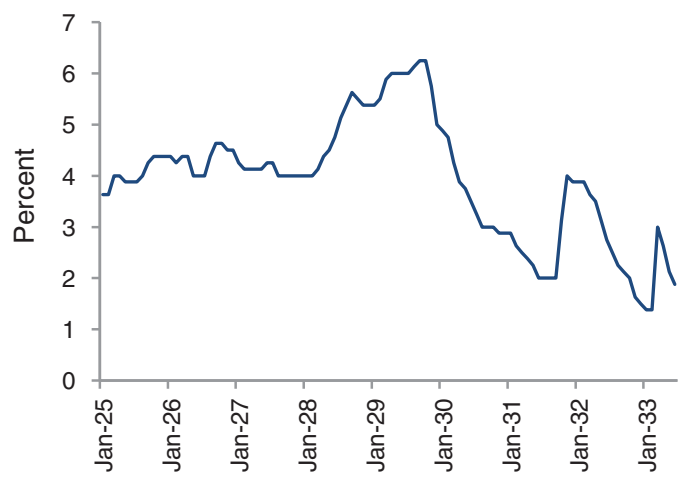

Figure 1. Commercial Paper Rate

Temin (1976) argues that the behavior of nominal rates in 1930 implies that the IS curve must have shifted back more than the LM curve. He posits an unusual drop in consumer spending as the culprit but cannot identify a cause. Romer (1990) suggests that a rise in income uncertainty associated with the stock market crash may have been the source. Olney (1999) argues that the particulars of consumer credit contracts led households to cut spending to ensure their ability to pay credit charges.

Bernanke (1983) hypothesizes that the panics affected spending directly by reducing credit supply at a given level of the safe interest rate. There is certainly some evidence of such effects, but evidence that they were big enough to account for the output decline is lacking.

Our assessment is that nonmonetary (IS) shocks were clearly present in the Depression, and possibly predominant in the first year. But scholars have not persuasively identified large nonmonetary shocks for the critical period from roughly late 1930 to early 1933 .

\section{An Alternative Transmission Mechanism}

The other way researchers have sought to reconcile Friedman and Schwartz's monetary hypothesis with the behavior of nominal rates is to bring in the rapid deflation that began in late 1929. Wholesale prices fell 17.5 percent between July 1929 and December 1930, and another 13.9 percent over 1931.2 If the deflation

\footnotetext{
${ }^{2}$ The data are from the Bureau of Labor Statistics, http:// www.bls.gov/data/, Series WPU00000000.
} 
was expected, real rates could have risen even as nominal rates declined. Indeed, in the IS-LM framework presented in terms of real output and the nominal interest rate, a rise in expected deflation enters as a shift back of the IS curve.

This insight led to a cottage industry of papers studying whether the deflation of the early 1930s was expected. Hamilton (1992), using data on commodities futures prices, argues that it was not, at least before 1931. Cecchetti (1992), using statistical forecasts as a proxy for expectations formation, argues that it was. Nelson (1991), in perhaps the most convincing study of the three, examines the business press from June 1929 to December 1930 and finds that professional observers were expecting deflation at least as early as mid-1930.

But, for the monetary story to be right, it is not enough that the deflation was expected. If the expectations resulted from the initial fall in output or supply shocks, those factors would be the ultimate source of the continued downturn. Thus, the monetary explanation requires that the expectations of deflation were driven by the monetary contraction. The rest of this paper therefore seeks to provide evidence on the source of the expectations of deflation.

\section{Expectations of Deflation and Monetary Developments}

There are many ways to try to obtain evidence about a possible link between monetary shocks and expected deflation during the Depression. The approach that we use is to examine one component of the business press closely for the first two years of the Depression.

The particular source we consider is The Business Week magazine. During the downturn, Business Week sometimes discussed what market participants were expecting to happen to prices. But for the most part, it simply gave its own views. So this source can show whether the expectations of deflation of a well-informed contemporary observer were driven by monetary developments.

Most of Business Week's discussion of price movements involved commodity prices. However, the magazine was very clear that it believed overall prices and wages would eventually follow commodity prices down (see, for example, $5 / 28 / 30$, p. 5).

\section{A. Business Week's Model of Deflation}

One important piece of evidence that Business Week's expectations of deflation were affected by monetary changes comes from its discussions of the causes of deflation. If price declines were attributed to monetary contraction, expectations of monetary contraction would likely create expectations of deflation.

Throughout 1930 and 1931, credit contraction was viewed as the central cause of overall deflation. For example, in March 1930, Business Week discussed the historical precedents for commodity price deflation. It stated $(3 / 12 / 30$, p. 20):

Two factors have been present in all of these periods of falling commodity prices - a marked rise in production and stocks of commodities on hand, and contraction in bank credit....

Relative contraction of bank credit during periods of increasing production and stocks has probably been the most important factor.

Likewise, in October 1931, it referred to "[t]he decline of prices and the rise in the value of money during the past two years, due to drastic contraction of credit" $(10 / 21 / 31$, p. 48).

Though Business Week referred mainly to credit, it viewed this term as roughly synonymous, or at least closely related, to "money." In an editorial discussing the causes of deflation, it said $(9 / 9 / 31$, p. 44):

They are symptoms of $\ldots$ a sudden, mysterious, universal shrinkage and shortage of the money and credit medium by which everything is exchanged and the supply of which rests solely in the hands of the world's banking institutions.

Business Week's discussion of the causes of some particular episodes of deflation shows that it believed Federal Reserve policy was an important determinant of the supply of money and credit. For example, in March 1930, it stated $(3 / 12 / 30$, p. 20$)$ :

The recent period of falling commodity prices, beginning in September, 1928, coincides with a period in which the rate of expansion of bank credit in the Federal Reserve System in this country began to decline relative to the 
increase in production, largely because of the efforts of the Federal Reserve authorities to control security speculation.

An analysis of wage deflation in mid-1931 again reveals a link between credit contraction and Federal Reserve policy (8/5/31, p. 40$)$ :

\begin{abstract}
The two fundamental factors affecting wages and employment during this depression have been credit policy of our banking system as affected by Federal Reserve operations, and trade organizing activity.... [A]ppropriate, prompt and aggressive action by the Reserve authorities could have ... checked the deflation of prices and wages.
\end{abstract}

Business Week's belief that credit contraction led to deflation and that Federal Reserve policy affected credit supply makes it plausible that expectations of deflation were also affected by credit supplies and Federal Reserve actions. The next two sections look for a more direct link between Business Week's expectations and its perceptions of Federal Reserve policy.

\section{B. Expectations of Deflation and Federal Reserve Policy in 1930}

Business Week began 1930 fairly optimistic about the end of deflation. Its January 1 issue said, "Prices, wages and employment will be somewhat, but not much, lower in 1930 than in 1929" (p. 22). It did not give a clear reason for this prediction, but expectations about monetary policy seem to have played a role. At the end of January, it said: "Business revival would probably be facilitated and not much endangered by a further lowering of rediscount rates. We should expect this any week now" (1/29/30, p. 4).

As deflation continued, however, the magazine became less sanguine. It wrote at the end of February (2/26/30, p. 4):

The unexpected commodity price deflation since the market crash has apparently given a second and more serious shock to business itself. This is a deferred result of credit restriction a year ago, which still persists.

It appeared to fear continued commodity price deflation because of Federal Reserve inaction, saying, "Continued weakness in commodity prices indicates plainly enough that markets are dull and doubtful.... All these things show clearly the effect of delay in credit expansion" $(3 / 12 / 30$, p. 4$)$.

In late June, when the New York Federal Reserve lowered its discount rate further, Business Week was enthusiastic. In July it listed "Eight Solid Facts That Point to Business Upturn," of which expanding bank credit was number one. It said: "This means that, so long as this expansion continues, either price levels or the volume of business activity is bound to rise—or both" (7/9/30, p. 5).

Two things are apparent from this discussion of the first half of 1930. One is that Business Week was not consistently expecting much deflation. If the magazine was representative of market participants, this suggests that some other force, such as Temin's autonomous drop in consumption, was driving down nominal interest rates in this period.

The other is that Business Week believed that adequate monetary expansion would stop the price declines. When the Federal Reserve showed signs of acting, the magazine expected it to be helpful. This is strong evidence that the magazine used credit and monetary policy developments in formulating its expectations of price movements.

By mid-July, Business Week was nervous that monetary expansion would not be forthcoming. It wrote $(7 / 16 / 30$, p. 41$)$ :

The Federal Reserve system did not follow up that aggressiveness of last week which had caused a short flurry of excitement. The large increase in Reserve credit at that time had encouraged hopes that the system was setting out actively to combat declining prices.

In early August, it reported: “[T]he Federal Reserve system, instead of continuing a helpful release of credit to counteract the creeping paralysis of deflation, has done nothing" (8/6/30, p. 10).

Despite this concern, Business Week did not consistently expect deflation in August and September. For example, in September it said that a turning point for commodity prices might be at hand $(9 / 24 / 30$, p. 7$)$. This suggests that other factors, such as its sense that prices simply could not fall below prewar levels, were also 
affecting its expectations (for example, $7 / 2 / 30$, p. 6 , and $9 / 17 / 30$, p. 44).

It was only in October that Business Week became clearly gloomy. It connected its expectations of deflation in part to Federal Reserve inaction, speaking of "the wave of uncontrolled deflation which financial fatalism and lack of business statesmanship in this country let loose upon the world" (10/22/30, cover). Its editorial said (p. 40):

The deflationists are in the saddle....

With the three largest banks lined up on their side ... and with the Federal Reserve authorities standing idly by, it has become clear since the middle of September that what was a comparatively mild business recession during the first half of 1930 has now become a case of world-wide reckless deflation.

The first wave of banking panics, which Friedman and Schwartz identify as starting in October 1930, did not show up in Business Week until December. The failure of the Bank of the United States was reported without fanfare in a short article in the middle of the magazine $(12 / 17 / 30$, p. 17). The outlook summary on the cover said:

[T] he tidal wave of deflation... has not altogether subsided.... The bond market has been seriously weakened by receding investment confidence and lack of Federal Reserve support.... [T]he deadly contraction of credit continues.

Clearly, Business Week was expecting continued deflation in part because of credit contraction caused by the interaction of the panics and Federal Reserve inaction. However, unlike Friedman and Schwartz, it viewed the inaction during the panic largely as a continuation of a general pattern of inadequate response to declining credit availability, rather than a distinct policy failure.

\section{Expectations of Deflation and Federal Reserve Policy in 1931}

Business Week began 1931 fairly optimistic, in part because of a discount rate cut at the end of December. On January 7, it stated (cover; dots of ellipsis in original):
Basic commodity prices seem to have exhausted the possibilities of further decline.... Though the tangible effects of lowered Federal Reserve rediscount rates on the bond market are still to be tested, increasing support may be expected.

But this optimism gave way to predictions of continued deflation as additional Federal Reserve actions failed to materialize. In February, it said: "The deflationists are now dominant in every aspect of public and private policy. Federal Reserve credit is being steadily contracted; ... commodity prices still drift downward" (2/4/31, cover). In an editorial in April, it said: "aggressive, persistent open-market operations by the Federal Reserve Banks could have compelled [banks] to cut short the chronic contraction of credit which has prolonged depression... [and] this drifting, demoralizing deflation" (4/15/31, p. 48).

In late April, the magazine gave one of its clearest statements that it was expecting continued deflation because of low levels of credit and anticipated Federal Reserve inaction. It said, "Our idle gold hoard piles up without increasing the means of payment by credit expansion because of paralysis of banking policy, thus prolonging price deflation" (4/29/31, cover).

In May, the Federal Reserve cut its discount rate again, and Business Week expressed more optimism about price movements. In June, it said of commodity prices, "A drastic and sudden reversal of the downward trend is not impossible or unlikely." One reason was, "Low money rates for short term commercial loans now enforced by Federal Reserve and European central bank policy will stimulate speculation for the rise and encourage consumers to accumulate supplies somewhat in excess of future requirements" $(6 / 10 / 31$, p. 9$)$.

However, when aggressive action failed to materialize and further banking troubles emerged, Business Week became more concerned. On September 9, it talked about "the seemingly unappeasable demand for cash," and said, "Federal Reserve policy continued to make their assistance available only in such a way as to increase the strain on the banks" (p. 41). The cover summary said that " $[t]$ he drastic decline in commodity prices, resumed in August," suggesting that the magazine may have started expecting more deflation. It drew a link between policy inaction and this expectation when it said, "The 
'wait and see' school is still in the ascendancy, and signs of the large-scale effort necessary to check the process are still lacking" (9/9/31, cover). And, two weeks later, it again linked its expectations of deflation to its expectations about monetary policy $(9 / 23 / 31$, cover $)$ :

The comparative steadiness of commodity averages is encouraging but conceals a still unstable price situation. ... Persistent inaction in official and financial circles in face of continued uncontrolled deflation becomes increasingly alarming.

When Britain went off the gold standard, Business Week became more worried that monetary developments would speed deflation. On October 7, it reported (p. 8):

In the United States the Reserve system is being subjected not only to the strain of these foreign withdrawals, but to a persistently increasing internal hoarding demand for currency ....

All this, taken in connection with the tidal wave of wage cuts, means further deflation in this country, as commodity prices decline, foreign trade is further hampered and credit becomes more costly and scarce.

This episode, like the others we have discussed, shows a link between expectations of deflation and monetary policy actions in one informed observer in the early 1930s. The other fact that these episodes drive home is the volatility of Business Week's expectations of deflation. It clearly changed its views about future price movements frequently. Based on our reading, a large fraction of these changes in price expectations, especially the longer-lasting ones, were due to changes in anticipated monetary and credit conditions.

\section{Conclusion}

This paper has sought to address an important weakness in Friedman and Schwartz's monetary explanation of the Great Depression: the lack of a well-articulated and documented transmission mechanism for the monetary shocks. Building on previous work, we emphasize the role of expected deflation in raising real interest rates. Our contribution is to show that the monetary explanation requires not just that there were expectations of deflation in the early 1930s; they must have been the result of the monetary contraction.

Our analysis of Business Week shows that such a link between monetary contraction and expected deflation existed strongly in this source. Perceived Federal Reserve action (or, often, inaction) was frequently given as the reason for the monetary contraction and the magazine's price expectations. If this result holds up in other narrative sources, it would provide important confirmation of the monetary explanation of the Depression.

This finding may also have implications for monetary policy and the transmission mechanism in other periods, such as later in the 1930s and in recent years. When nominal interest rates are at the zero lower bound, expansionary monetary policy can increase output in part by raising expectations of inflation and lowering real interest rates. Based on Business Week's expectation formation process in the early 1930s, it appears that expansionary policy may indeed create such expectations.

\section{REFERENCES}

Bernanke, Ben S. 1983. "Nonmonetary Effects of the Financial Crisis in the Propagation of the Great Depression." American Economic Review 73 (3): 257-76.

Board of Governors of the Federal Reserve System. 1943. Banking and Monetary Statistics. Washington, DC: The National Capital Press.

The Business Week. 1930 and 1931.

Cecchetti, Stephen G. 1992. "Prices during the Great Depression: Was the Deflation of 19301932 Really Unanticipated?" American Economic Review 82 (1): 141-56.

Friedman, Milton, and Anna Jacobson Schwartz. 1963. A Monetary History of the United States, 1867-1960. Princeton: Princeton University Press.

Hamilton, James D. 1987. "Monetary Factors in the Great Depression." Journal of Monetary Economics 19 (2): 145-69.

Hamilton, James D. 1992. "Was the Deflation during the Great Depression Anticipated? Evidence from the Commodity Futures Market." American Economic Review 82 (1): 157-78. 
Nelson, Daniel B. 1991. "Was the Deflation of 1929-1930 Anticipated? The Monetary Regime as Viewed by the Business Press.” In Research in Economic History, Vol. 13, edited by Roger L. Ransom, 1-65. Greenwich, CT: JAI Press.

- Olney, Martha L. 1999. "Avoiding Default: The Role of Credit in the Consumption Collapse of 1930." Quarterly Journal of Economics 114 (1): 319-35.

-Romer, Christina D. 1990. "The Great Crash and the Onset of the Great Depression." Quarterly Journal of Economics 105 (3): 597-624.

Temin, Peter. 1976. Did Monetary Forces Cause the Great Depression? New York: Norton. 